\title{
Vibrio vulnificus AS A HEALTH HAZARD FOR SHRIMP CONSUMERS
}

\begin{abstract}
SUMMARY
Over the last 30 years, a number of Vibrio species found in the aquatic environment have been indicated as cause of disease in human beings. Vibrio vulnificus is an emergent pathogen, an invasive and lethal marine bacterium related to wound infection and held accountable for gastroenteritis and primary septicemia. It occurs quite frequently in marine organisms, mainly in mollusks. This study aimed at isolating and identifying strains of $V$. vulnificus based upon the analysis of twenty samples of seabob shrimp, Xiphopenaeus kroyeri (Heller), purchased at the Mucuripe fish market (Fortaleza, Brazil). TCBS agar was used to isolate suspect strains. Seven of twenty-nine strains isolated from six different samples were confirmed as such by means of biochemical evidence and thus submitted to biological assays to determine their virulence. The susceptibility of the $V$. vulnificus strains to a number of antibiotics was tested. None of the V. vulnificus strains showed signs of virulence during a 24-hour observation period, possibly due to the shedding of the capsules by the cells. As to the results of the antimicrobial susceptibility tests, the seven above-mentioned V. vulnificus strains were found to be sensitive to nitrofurantoin (NT), ciprofloxacin (CIP), gentamicin (GN) and chloramphenicol (CO) and resistant to clindamycin (CI), penicillin (PN) and ampicillin (AP).
\end{abstract}

KEYWORDS: Marine bacterium; Vibrio vulnificus; Shrimp; Antimicrobial susceptibility tests.

\section{INTRODUCTION}

The consumption of both mollusks and crustaceans - among the latter, especially shrimp - has been on the increase over the past years. According to the Brazilian Ministry of Agriculture, fishing industries in Ceará exported 320,500 kg, 953,109 kg and 997,213 kg in 1988, 1999 and 2000, respectively. Unfortunately these foods have also been implied in outbreaks of intoxication and intestinal infection produced by naturally occurring marine and estuarine bacteria. Most of these bacteria are vibrionaceans belonging to genus Vibrio. Studies describing the presence of vibrions in seafood in temperate regions and in Asia are quite common, and a few instances of vibrion-related disease, apart from Vibrio cholerae 01 , have been reported from tropical countries. The few reports available on the occurrence of these microorganisms in seafood, deal mostly with Vibrio parahaemolyticus. The species Vibrio vulnificus was first associated with disease in human beings in 1970 when a male patient was found to have developed an infection in the leg and diarrhea after swimming in the sea and collecting oysters ${ }^{22}$. However, the severity and frequency of $V$. vulnificus infections were not appreciated until in the late $1970 \mathrm{~s}^{3}$. Epidemiological enforcement teams in four American states along the Gulf of Mexico found an annual incidence of $V$. vulnificus infections of 0.6 million cases, with a mortality rate of $22 \%{ }^{16}$.

The present study aims at: 1) isolating and identifying V. vulnificus strains in marine shrimp samples, 2) investigating the toxigenic potential of the isolated bacteria through biological tests, and 3) assessing the susceptibility of these bacteria to a number of selected antibiotics.

\section{MATERIALS AND METHODS}

The standard Vibrio vulnificus strain used in all biochemical tests was provided by Fundação Oswaldo Cruz (FIOCRUZ) and maintained in $3 \% \mathrm{NaCl}$ tryptone soy agar (TSA) in a BOD incubator (model: 347 Fanem, Brazil) at $23{ }^{\circ} \mathrm{C}$.

Twenty seabob shrimp Xiphopenaeus kroyeri (Heller) (500 g total weight) were purchased from stalls at the Mucuripe fish market (Fortaleza, Ceará), iced and transported in isothermic containers to the Fish Microbiology laboratory of the Marine Sciences Institute (Instituto de Ciências do Mar - LABOMAR, Fortaleza).

A set of $25 \mathrm{~g}$ samples was homogenized in $225 \mathrm{~mL}$ of $3 \% \mathrm{NaCl}$ solution and subsequently diluted (from $10^{-1}$ to $10^{-3}$ ) in $9 \mathrm{~mL}$ of the same medium, then spread-plated on thiosulfate citrate bile saccharose (TCBS) agar and incubated for 24 hours at $35^{\circ} \mathrm{C}$. Suspect, 2-3 mm saccharosenegative, dull green colonies from the plates were isolated in TSA-DIFCO and incubated once more for 24 hours at $35{ }^{\circ} \mathrm{C}$ for biochemical confirmation $^{8}$.

(1) Instituto de Ciências do Mar - UFC, Ceará, Brasil.

(2) Dep. de Bacteriologia, Fundação Oswaldo Cruz, FIOCRUZ, Rio de Janeiro, RJ, Brasil

(3) Universidade do Vale do Acaraú - UVA, Ceará, Brasil.

Correspondence to: Dr. Regine Helena S. dos F. Vieira, Av. da Abolição 3207, Meireles, 60165-081 Fortaleza, Ceará, Brasil.( e.mail: regine@ labomar.ufc.br) 
The first tests involved oxidase and motility and used $1 \%$ tetramethylp-phenylenodiamine and SIM (DIFCO) medium, respectively. In both tests, positive strains were submitted to halophilism assays in $1 \%$ peptone broth at $0,3,6,8$ and $10 \% \mathrm{NaCl}$ concentrations, to ONPG and acetoine production assays, and finally to incubation for 24 hours at $35{ }^{\circ} \mathrm{C}$. The morphological characteristics of the isolated strains cultured in 3\% TSA were observed by gram staining.

The pathogenicity of the $V$. vulnificus strains isolated from the shrimp samples was tested in biological assays. The study employed seven groups of three mice each and an average individual weight of $20 \mathrm{~g}$. Each mouse was submitted to intraperitoneal inoculation with $0.1 \mathrm{~mL}$ of culture grown in brain heart infusion (BHI) for 24 hours at room temperature. The control consisted of a group of three mice submitted to inoculation with $0.1 \mathrm{~mL}$ of sterile BHI. All groups were observed for 24 hours $^{4}$.

The antimicrobial susceptibility tests were performed according to the methodology recommended by BAUER et al. ${ }^{1}$ and met the criteria established by the NCCLS ${ }^{18}$. The following CECON antibiotics were used in the tests: nitrofurantoin (NT), nalidixic acid (NA), tetracycline (TT), clindamycin (CI), tobramycin (TB), ciprofloxacin (CIP), penicillin $(\mathrm{PN})$, gentamicin $(\mathrm{GN})$, kanamycin $(\mathrm{KN})$, cefotaxime (CTX), erythromycin (EI), chloramphenicol (CO), amikacin (AM), ampicillin (AP) and sulfonamide (SF). The control strains used were Escherichia coli (ATCC 25922) and S. aureus (ATCC 25923).

\section{RESULTS AND DISCUSSION}

Seven of the 20 original samples yielded positive results. Our figures therefore indicate a rather high incidence as compared to that $(14.3 \%)$ found for shrimp by GARCIA-MORENO \& LANDGRAF $^{9}$. In an analysis of shrimp, oysters and mussels, LANDGRAF et al. ${ }^{15}$ found an even lower incidence for shrimp (4.2\%) and a relatively high incidence for oyster $(29.0 \%)$. It is a well-known fact that vibrions are found more often in oysters due to their filtering habits and their natural presence in the estuarine microbiota. It is therefore not uncommon for oysters to accumulate all types of viruses and bacteria which occur in the surrounding water.

The results reported so far regarding the isolation of Vibrio vulnificus from shrimp have been controversial. While DePAOLA et $a l .{ }^{7}$ isolated a $4.4 \log$ MPN of bacteria in crustacean samples, DALSGAARD \& $\mathrm{HOI}^{5}$ found only 3 vibrion-contaminated samples (7\%) out of a batch of 46 in a study using raw, frozen shrimp imported from Thailand and Indonesia. However, the authors found no contamination in 61 cooked and frozen products imported from these same countries. In view of the uncertainty of the matter and the lack of precise knowledge about the infecting dose of $V$. vulnificus, it would be desirable to establish a maximum number of bacteria allowed in seafood, both as a reference for researchers and as a safeguard for consumers.

Epidemiological data indicate that in the presence of immunocompromising disease and liver damage the infecting dose of this potentially fatal microorganism may be extremely $\operatorname{low}^{20}$.

Studies carried out in Florida show that less than 15\% of high-risk patients were aware of the hazards associated with the consumption of raw oysters ${ }^{14}$. Through a popular awareness program focused on the risk of infection associated with this pathogen, the Florida Health and Rehabilitation Service has been informing the general population and providing gastroenterologists with clinical references and data of relevance to patients suffering from chronic liver infection. In California and Louisiana, raw oyster vendors are obliged to put up clearly visible signs informing customers about the risk of consuming this product ${ }^{12}$.

Our biological tests did not confirm the pathogenicity of the isolated strains. The 21 mice inoculated with a $V$. vulnificus culture displayed no symptoms even after 24 hours of observation. This fact may be explained by the loss of the polysaccharide capsule without which, according to OLIVER \& KAPER ${ }^{20}$, vibrions cannot initiate an infection. SIMPSON et al. ${ }^{21}$ observed that the absence of the capsule was tied up with the loss of virulence of the strains; in fact, only encapsulated cells were able to make use of transferrin-bound iron and a $10^{3}$ inoculum was virulent to mice when iron was abundant in the blood serum.

It is interesting to note that the colonies grown in TSA with $1 \%$ $\mathrm{NaCl}$ for 24 hours produced no mucus and easily lost their shape at the touch of a platinum needle. When placed under light the colonies turned out to be translucid. According to OLIVER \& $\mathrm{KAPER}^{20}$, V. vulnificus colonies are either opaque (virulent) or translucid (not virulent). The encapsulated form is a common type in clinical isolates and is associated with invasion capacity, while the harmless unencapsulated form is more common in the environment ${ }^{11}$.

It has been suggested that unencapsulated cells cannot take up transferrin, and that only opaque cells are capable of growing in human transferrin while resisting the bactericidal and bacteriostatic effects inherent in human blood serum ${ }^{21}$. However, this has been questioned by WRIGHT et al. ${ }^{23}$, who reported the growth of an unencapsulated strain in human transferrin.

The earliest virulence tests using latent cells revealed a loss of pathogenicity in both common and iron-primed mice ${ }^{17}$. However, recent studies have shown that this human pathogen retains its virulence in a non-cultivable state ${ }^{19}$. BIOSCA et al. ${ }^{2}$ found that latent cells were not virulent to elvers or mice, regardless of the cell morphotype chosen. The authors proposed that the loss of infectiousness of cells in a non-cultivable state may be due to factors other than the loss of the capsule. The same authors observed that the loss of virulence occurred only in cells stressed by exposure to low temperatures.

When challenged with antibacterial agents, all isolated strains were sensitive to nitrofurantoin, ciprofloxacin, gentamicin and chloramphenicol, and resistant to ampicillin. Table 1 lists the antibiotics which were efficient against $V$. vulnificus strains in the susceptibility tests. Clindamycin, penicillin, ampicillin and sulfonamide, on the other hand, were not efficient against the colonies. HORRÉ et al. ${ }^{13}$ likewise evaluated the susceptibility of $V$. vulnificus and found it to be sensitive to several antibiotics.

The most efficient antibiotics tested in this study were nitrofurantoine, ciprofloxacin, gentamicin and chloramphenicol.

Studies carried out by BIOSCA et al. ${ }^{2}$ using combinations of ampicillin with cefotaxime, tetracycline, amoxillin plus gentamicin or chloramphenicol associated with aminoglycosides yielded satisfactory 
Table 1

Susceptibility of Vibrio vulnificus strains isolated from samples of seabob shrimp, Xiphopenaeus kroyeri (Heller), to antimicrobial agents

\begin{tabular}{|c|c|c|c|c|c|c|c|}
\hline \multirow[b]{2}{*}{ Antibiotic/Disk content } & \multicolumn{7}{|c|}{ Strains/Samplings } \\
\hline & 1 & 2 & 6 & 10 & 14 & $14 \mathrm{a}$ & 19 \\
\hline 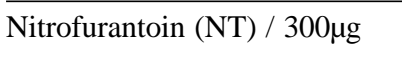 & $\mathrm{S}$ & $\mathrm{S}$ & $S$ & $\mathrm{~S}$ & $\mathrm{~S}$ & $\mathrm{~S}$ & $\mathrm{~S}$ \\
\hline Nalidixic acid (NA) / 30 $\mu \mathrm{g}$ & $\mathrm{S}$ & $S$ & $S$ & $\mathrm{R}$ & $\mathrm{S}$ & I & $\mathrm{R}$ \\
\hline Tetracycline (TT) / 30ug & $\mathrm{S}$ & $\mathrm{R}$ & $S$ & $\mathrm{~S}$ & $\mathrm{~S}$ & $\mathrm{~S}$ & $\mathrm{R}$ \\
\hline Clindamycin $(\mathrm{CI}) / 2 \mu \mathrm{g}$ & $\mathrm{R}$ & $\mathrm{R}$ & $\mathrm{R}$ & $\mathrm{R}$ & $\mathrm{R}$ & $\mathrm{R}$ & I \\
\hline Tobramycin (TB) / 10ug & $\mathrm{S}$ & $\mathrm{S}$ & $S$ & $\mathrm{~S}$ & $\mathrm{~S}$ & $\mathrm{~S}$ & I \\
\hline Ciprofloxacin (CIP) / 5 $\mu \mathrm{g}$ & $\mathrm{S}$ & $\mathrm{S}$ & $S$ & $\mathrm{~S}$ & $\mathrm{~S}$ & $\mathrm{~S}$ & $\mathrm{~S}$ \\
\hline Penicillin (PN) / 10U & $\mathrm{R}$ & $\mathrm{R}$ & $\mathrm{R}$ & $\mathrm{R}$ & $\mathrm{R}$ & $\mathrm{R}$ & $\mathrm{R}$ \\
\hline 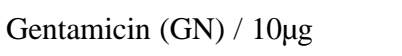 & $\mathrm{S}$ & $\mathrm{S}$ & S & $\mathrm{S}$ & $\mathrm{S}$ & S & $\mathrm{S}$ \\
\hline Kanamycin $(\mathrm{KN}) / 30 \mu \mathrm{g}$ & I & I & I & $\mathrm{S}$ & $\mathrm{S}$ & $\mathrm{S}$ & $\mathrm{R}$ \\
\hline 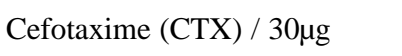 & $\mathrm{S}$ & MS & MS & $\mathrm{S}$ & $\mathrm{S}$ & MS & $\mathrm{S}$ \\
\hline 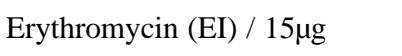 & $\mathrm{S}$ & $\mathrm{S}$ & $S$ & $\mathrm{~S}$ & $\mathrm{~S}$ & I & $\mathrm{R}$ \\
\hline 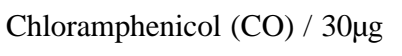 & $\mathrm{S}$ & $\mathrm{S}$ & $S$ & $\mathrm{~S}$ & $\mathrm{~S}$ & S & $\mathrm{S}$ \\
\hline 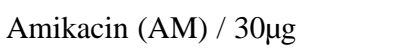 & I & $\mathrm{I}$ & I & $\mathrm{S}$ & I & $\mathrm{S}$ & $\mathrm{R}$ \\
\hline 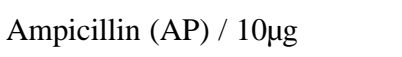 & $\mathrm{R}$ & $\mathrm{R}$ & $\mathrm{R}$ & $\mathrm{R}$ & $\mathrm{R}$ & $\mathrm{R}$ & $\mathrm{R}$ \\
\hline 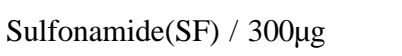 & $\mathrm{S}$ & $\mathrm{S}$ & $\mathrm{R}$ & $\mathrm{R}$ & $\mathrm{S}$ & $\mathrm{R}$ & $\mathrm{R}$ \\
\hline
\end{tabular}

Source: BAUER et al., 1966. R - Resistant; I - Intermediary; MS - Moderately susceptible; S- Susceptible.

therapeutic results. It should be pointed out that in the case of both skin infections and primary septicemia the use of antibiotics is highly recommended to prevent clinical complications ${ }^{10}$. Currently the most efficient antibiotics for the treatment of infections caused by V. vulnificus ${ }^{6}$ include tetracycline, the fluoroquinolones (e.g. ciprofloxacin), third generation cephalosporines (e.g. ceftazidime) and the aminoglycosides (e.g. gentamicin) which are therapeutically associated with ceftazidime and tetra or doxacillin, or even doxacillin in combination with ciprofloxacin or an aminoglycoside.

This therapeutic procedure can minimize the morbidity and mortality associated with $V$. vulnificus infections. However, an indiscriminate use of antibiotics has in some areas induced the development of resistance in autochthonous bacteriological samples isolated from aquatic environments. In one of their studies, BIOSCA et al. ${ }^{2}$ isolated tetracycline- and trimethoprim-resistant biotype I strains from an aquatic environment.

The strains were not virulent in our biological assays, but the results of the antibiograms are a source of concern since many strains showed resistance to antibiotics such as penicillin, ampicillin and clindamycin. This finding is of relevance to public health professionals since it indicates that strains with resistant genes circulate in the environment. The situation is aggravated by the fact that exchanges or transfer of plasmids between microorganisms in the original environment of the shrimp are likely to have a negative impact on consumers of shrimp, especially in its raw form.

\section{RESUMO \\ Vibrio vulnificus: um fator de risco para a saúde do consumidor de camarões}

Nos últimos 30 anos várias espécies de Vibrio que vivem em ambientes aquáticos têm sido proclamadas como vetor de doenças que atingem o ser humano. Vibrio vulnificus é um patógeno de origem marinha, com potencial invasor, podendo ser letal. Tem sido relacionado com feridas infeccionadas e responsável por incontáveis casos de gastrenterites e septicemia primária. Sua frequência em organismos marinhos é considerada alta, principalmente em moluscos. Este trabalho objetivou isolar e identificar cepas de Vibrio vulnificus a partir de 20 amostras de camarão sete- barbas, Xiphopenaeus kroyeri (Heller), comercializado na feira de pescado do Mucuripe, Fortaleza, Ceará, Brasil. O ágar TCBS foi usado para isolamento primário e as cepas confirmadas através de provas bioquímicas eram submetidas a testes de virulência em camundongos. Posteriormente as cepas identificadas como Vibrio vulnificus foram testadas em relação à susceptibilidade a antimicrobianos. De 29 cepas, isoladas de 20 amostras, sete (35\%), originadas de sete diferentes amostras, foram confirmadas como Vibrio vulnificus, significando alta percentagem de amostras contaminadas. Nenhuma das cepas apresentou virulência após 24 horas de observação, possivelmente devido à perda das cápsulas pela célula. As sete cepas de Vibrio vulnificus mostraram-se sensíveis a nitrofurantoína (NT), ciprofloxacina (CIP), Gentamicina (GN), Cloranfenicol (CO), mas resistentes a Clindamicina (CI), Penicilina (PN) e a Ampicilina (AP). 


\section{REFERENCES}

1. BAUER, A.W.; KIRBY, W.M.M.; SHERRIS, J.C. \& TURCK, M. - Antibiotic susceptibility testing by a standardized single disc method. Amer. J. clin. Path., 45: 493-496, 1966.

2. BIOSCA, E.G.; OLIVER, J.D. \& AMARO, C. - Phenotypic characterization of Vibrio vulnificus biotype 2, a lipopolysaccharide-based homogeneous $\mathrm{O}$ serogroup within Vibrio vulnificus. Appl. environ. Microbiol., 62: 918-927, 1996.

3. BLAKE, P.A.; MERSON, M.H.; WEAVER, R.E.; HOLLIS, D.G. \& HEUBLEIN, P.C. Disease caused by a marine Vibrio: clinical characteristics and epidemiology. New Engl. J. Med., 300: 1-5, 1979.

4. BOWDRE, J.H.; POOLE, M.D. \& OLIVER, J.D. - Edema and hemoconcentration in mice experimentally infected with V. vulnificus. Infect. Immun., 32: 1193-1199, 1981.

5. DALSGAARD, A. \& HØI, L. - Prevalence and characterization of Vibrio vulnificus isolated from shrimp products imported into Denmark. J. Food protect., 60: 1132-1135, 1997.

6. DANIELS, N.A. \& SHAFAIE, A. - A review of pathogenic Vibrio infections for clinicals. Infect. Med., 17: 665- 685, 2000.

7. DEPAOLA, A.; MCLEROY, S. \& MCMANUS, G. - Distribution of Vibrio vulnificus phage in oyster tissues and other estuarine habitats. Appl. environ. Microbiol., 63: 2464-2467, 1997.

8. ELLIOT, E.L.; KAYSNER, C.A. \& TAMPLIN, M.L. - V. cholerae, V. parahaemolyticus, V. vulnificus, and other Vibrio spp. In: Bacteriological analytical manual. 7. ed. Arlington, Association of Official Analytical Chemists, 1992. p. 111-140.

9. GARCIA-MORENO, M.L. \& LANDGRAF, M. - Ocorrência de Vibrio vulnificus em alguns alimentos de origem marinha. Rev. Ciênc. Tecnologia de Alimentos - SBCTA, 17 (2): 177-180, 1997.

10. Gilbert, D.N.; MOELlering, R. C. \& SANDE, M.A. - Sanford guide to antimicrobial therapy. 29. ed. Hyde Park, Antimicrobial Therapy, 1999.

11. HAYAT, U.; REDDY, G.P.; BUSH, C.A. et al. - Capsular types of V.vulnificus: an analysis of strains from clinical and environmental sources. J. infect. Dis., 168: 758-762, 1993.

12. HLADY, W.G.; MULLEN, R.C. \& HOPKINS, R.S. - Vibrio vulnificus from raw oysters: leading cause of reported deaths from foodborne illness in Florida. J. Fla. med. Ass., 80: 536-538, 1993.
13. HORRÉ, R.; MARKLEIN, G. \& SCHAAL, K.P. - Vibrio vulnificus, an emerging human pathogen. Zbl. Bakt., 284: 273-284, 1996.

14. JOHNSON, A.R.; ANDERSON, C.R. \& RODRICK, G.E. - A survey to awareness of hazards related to raw seafood ingestion in at risk patient groups. In: ANNUAL CONFERENCE OF THE TROPICAL AND SUBTROPICAL FISHERIES TECHNOLOGY SOCIETY OF THE AMERICAS, 13., 1988. Proceedings.

15. LANDGRAF, M.; LEME, K.B.P. \& GARCIA-MORENO, M.L. - Occurrence of emerging pathogenic Vibrio spp in seafood consumed in São Paulo City, Brazil. Rev. Microbiol. 27: 126-130, 1996.

16. LEVINE, W.C. \& GRIFFIN, P.M. - Vibrio infections on the Gulf Coast: results of a first year of regional surveillance. Gulf Coast Vibrio working group. J. infect. Dis., 167: 479-483, 1993.

17. LINDER, K. \& OLIVER, J.D. - Membrane fatty acid and virulence changes in the viable but nonculturable state of Vibrio vulnificus. Appl. environ. Microbiol., 55: 2837$2842,1989$.

18. NATIONAL COMMITTEE FOR CLINICAL LABORATORY STANDARDS (NCCLS) - Performance standards for antimicrobial disk susceptibility tests M 190. v. 19, 1999.

19. OLIVER, J.D. \& BOCKIAN, R. - In vivo resuscitation, and virulence towards mice, of viable but nonculturable cells of Vibrio vulnificus. Appl. environ. Microbiol., 61: 2620-2623, 1995.

20. OLIVER, J.D. \& KAPER, J.B. - Vibrio species. In: DOYLE, M.P.; BEUCHAT, L.R.\& MONTVILLE, T.J., ed. Food Microbiology: fundamentals and frontiers. Washington, ASM, 1997. p. 228-264.

21. SIMPSON, L.M.; WHITE; V.K.; ZANE, S.F. \& OLIVER, J.D. - Correlation between virulence and colony morphology in Vibrio vulnificus. Infect. Immun., 55: 269$272,1987$.

22. WICKBOLDT, L.G. \& SANDERS, C.V. - Vibrio vulnificus infection. Case report and update since 1970. J. Amer. Acad. Derm., 9: 243-251, 1983.

23. WRIGHT, A.C.; SIMPSON, L.M.; OLIVER, J.D. \& MORRIS Jr, J.G. - Phenotypic evaluation of acapsular transposon mutants of Vibrio vulnificus. Infect. Immun., 58: 1769-1773, 1990.

Received: 08 June 2001

Accepted: 14 September 2001 